\title{
Revitalization of Pancasila Values Against the Imposition of Substitution Money as an Additional Criminal in Corruption Crimes
}

\author{
David P. Duarsa \\ Student of Doctor of Law Studies Program \\ Lampung University \\ Lampung, Indonesia \\ Email: davidpduarsa@gmail.com
}

\author{
Dauri \\ Student of Master of Law Study \\ Lampung University \\ Lampung, Indonesia \\ Email: dauri170996@gmail.com
}

\begin{abstract}
This study aims to examine the values of Pancasila against the imposition of substitute money for the crime of Corruption. The value of Pancasila has its meaning that must be applied both in social, political, legal, and economic life. The law means that every crime committed by a criminal must be given a basic criminal sanction as well as additional criminal sanctions, which as a whole cannot be separated from the application of the values contained in Pancasila. The method used in this research is socio-legal, with a conceptual approach and a philosophical approach. The application of sanctions given to corruption perpetrators is sometimes only limited to imprisonment, not to restore state losses, this is considered unfair in applying the values contained in Pancasila. The revitalization of Pancasila will make efforts to excavate the norms, philosophy of Pancasila to become the spirit and foundation for the formation of moral guidance and become the basis for legal norms in Indonesia. The urgency in the relevance of the value of Pancasila as substitute money for corruption in Indonesia is to restore state losses based on the values of Pancasila. The payment of compensation in practice does not protect the economic rights of the community that has been lost over time until the decision has permanent legal force, the payment of compensation is only based on the amount obtained by the defendant. The problems encountered in recovering state financial losses through the imposition of sanctions for payment of compensation for corruption include; the convict does not pay the replacement money charged to him, and the convict does not have sufficient property to pay the replacement money charged to him.
\end{abstract}

Keywords-Pancasila, Replacement Money, and Corruption

\section{INTRODUCTION}

The Pancasila philosophy is the national identity of the Indonesian nation because of the noble values of the Indonesian nation's personality, namely theology, polite respect for each other, upholding human rights, cooperation, patriotism and nationalism, and justice in all areas of life, all noble values These are accumulated into the philosophy of Pancasila [1]. Therefore, it is necessary to place Pancasila as the highest norm in the life of society, nation, and state.

Pancasila as the basis of the State has long historical roots in the history of Indonesia, the values inherent in it transcend the barriers of the subjectivity of civilization and time, therefore the birth of Pancasila on June 1, 1945, is not only an ideological concept but also as an ideology. ethical concept because there is no great nation that does not rely on an ideology rooted in the conscience of its people, because ideology is the guide to the direction of a nation in achieving its greatness. Ideology is the motive as well as hope for the people because the ideology of Pancasila is a set of values that not only embeds the idealization of the future picture of Indonesian society but also contains a set of values that are empirically rooted [2].

Law enforcement is carried out fairly and political policies are carried out proportionally based on the values that live in the community (living politics and law), public welfare and civility can certainly be realized [3]. On the other hand, if law enforcement is carried out only to realize the interests of the elite and is passionate about leaving a sense of justice not in favor of the weak, then the law is no longer sovereign and away from the basic values of the Pancasila ideology.

Pancasila is the nation's ideology and is also a paradigm or framework of thought, a source of values, and a direction orientation for law enforcement and political policy. That is why it is a necessity to carry out law and politics based on the values of Pancasila, namely Belief in God, Humanity, Unity, Democracy, and Justice. These values contain progressive meanings, namely (1) towards progress; and (2) leaning towards improving the situation. This is in line with Satjipto Rahardjo's idea of progressive law, namely directing laws that can follow the development 
of the times, can answer the problems that develop in society, and can serve the community by relying on the morality aspect of the resources of law enforcement officers as a response to the positivistic paradigm [4].

When a criminal act or disorder in society is committed by a person, it will result in a loss of balance in the society concerned, and cause suffering to the victim. As perpetrators of crimes, they should receive sanctions following social justice, and do not rule out the existence of Pancasila. It is the same with criminal acts of corruption committed by individuals or groups, which must be based on a punishment that is proportional to the sanction given.

The basis for sentencing must be sought in the crime itself because the crime causes suffering to others while the punishment is an absolute requirement of the law of decency. This theory is more famous for the absolute theory of sentencing, while according to the relative theory, it assumes that people who commit crimes are people who are lost in social interactions, so they need to be guided so that in the end when they return to society they become useful people and the combined theory is a theory. which in imposing a sentence on criminal offenders combines absolute theory and relative theory [5].

The rise of corruption in this country as a crime, its emergence has reached a threshold so that its eradication requires optimal and continuous efforts. Law Number 20 of 2001 concerning Amendments to Law Number 31 of 1999 concerning Eradication of Criminal Acts of Corruption in Article 18 paragraph (1) letter $b$ regulates the payment of replacement money in the maximum amount equal to property obtained from criminal acts of corruption. This article is an additional form of punishment that can be imposed on a corrupt defendant. The main crime accompanied by additional penalties is specifically in Article 2 and Article 3 of the Corruption Law which in the element of the offense mentions harming state finances or the state economy.

The imposition of imprisonment as a substitute for substitute money consistently between defendants is a form of embodiment of legal certainty and considerations for imposing a substitute for a high substitute money sentence can be given minimum and maximum limits, to provide a deterrent and at the same time close the opportunity for the convicts to choose a substitute for imprisonment instead choose to return the state money [6]. Perpetrators of criminal acts of corruption see that the result of a violation of the law is a risk, not from the side of the legal consequences that must be accepted, thus the profit and loss side is mathematically economically the main consideration for committing a criminal act of corruption. Determination of the minimum and maximum limits on substitutes for substitute money in the form of additional imprisonment,
The schedule for payment of replacement money as stated in the Anti-Corruption Law within a month, which then in the next stage is the confiscation of the convict's assets, does not clearly state the time required to complete the search/tracking of the convict's assets and the time required to conduct the auction process for the assets after the convict can be obtained by the state. Determination of the time limit for the process of finding the convict's assets for the return of state money, the period for the completion of the process of returning the state money should be determined so that the state immediately obtains the funds for development and provides legal certainty for the convict

Thus, in the relevance of Pancasila values, it is inseparable from legal reforms that can be a solution in recovering state losses arising as a result of criminal acts of corruption. Therefore, in this study, we will discuss issues relating to whether the urgency of the relevance of Pancasila values to the imposition of substitute money in criminal acts of corruption and its problems. The urgency is expected to be able to reconstruct the substitute money crime as an additional crime to become the main crime in corruption.

\section{LITERATURE REVIEW}

\section{A. The Essence of Pancasila Values}

Pancasila as the basis of the state means that Pancasila is used as the basis for the administration of the state. Pancasila as the basis of the state means that all government implementation and administration must reflect the values of Pancasila and must not conflict. Etymologically Pancasila comes from Sanskrit which means Pancasila means five and precepts means joint stone, base, and foundation [7]. Pancasila has five basic meanings, while the precepts themselves are often interpreted as conformity or rules of good behavior. The essence is something that exists in a person or something that must exist in oneself.

Pancasila is not something foreign to Indonesian citizens, it is applied in the preamble of the 1945 Constitution, paragraph IV, and is used as the basis of the Republic of Indonesia which consists of 5 precepts. Even though the 1945 Constitution is not directly explained about Pancasila, Pancasila has been embedded in the soul of the Indonesian people that Pancasila is a guideline that must be instilled in themselves. According to Suraya (2015: 154), Pancasila is the basis of the Indonesian state, Pancasila is likened to a foundation, so the stronger the foundation, the stronger a country will be. Pancasila also reflects the personality of the Indonesian people because in it there are items which if implemented will reflect the personality of the Indonesian nation [8].

Based on the above understanding, it can be concluded that the essence of Pancasila is something that is contained in the values contained in the Pancasila precepts which must be used as a cause so 
that it is used as the basis of the state. Pancasila shows the essence or substance of Pancasila, namely the basis or basic words of God, humans, people, and justice. Get the prefix and suffix ke-an, role, divinity, humanity, unity, democracy, and justice. The essence or substance has the nature of abstract, general, universal, absolute, fixed, unchanging, regardless of the situation, place, and time. The nature or substance is divided into three kinds, namely [9]:

- Abstract nature, called the nature of the type or general nature which has the same elements, is fixed and does not change. The permanent and unchanging nature is because from the past until now it has been recognized by mankind;

- Personal nature, namely the permanent elements that cause everything concerned to remain in the person, and

- The essence of concrete is real and clear. Every human being in reality. This concrete essence serves as a practical guide in the life of the Indonesian nation and state following daily realities, places, circumstances, and times.

Based on the description above, it can be concluded that Pancasila as the basis of the state has five precepts. Pancasila as a philosophy shows the nature or substance that is abstract (existing in the human mind since the first), personal (related to personal life), and concrete (realized in everyday life), general or universal, absolute, fixed, unchanging. , regardless of the situation, place and time.

The position of Pancasila as the basis of the state can be found in the constitutional basis that has ever existed in Indonesia. The foundation does not mention the term Pancasila but with the mention of the Pancasila precepts, thus these documents contain the Pancasila state basis. "Pancasila as the basis of the state implies that the values of Pancasila are used as the basic foundation in the administration of the state" [10]. Pancasila as the basis of the state means that all implementation and administration of government must reflect the values of Pancasila and must not conflict with Pancasila. According to Sulasmana (2015: 68) the meaning or role of Pancasila as the basis of the state of the Republic of Indonesia is the basis for the establishment and establishment of the state, the basis for state administration activities, the basis for citizen participation,

Pancasila can play a role as a unifier of the nation, maintain unity and integrity, and can direct the Indonesian nation to achieve the aspired goals. "Pancasila can give a picture of ideals and can be used as motivation and determination to achieve the ideals of the Indonesian nation [11]. The ideology of Pancasila can also provide determination to maintain the nation's identity. Pancasila can be used as a picture of the nation's identity so that with Pancasila the community can develop the character and identity of the Indonesian nation itself

\section{B. Corruption Crime}

Corruption is the misappropriation or embezzlement of state or company money as a place for someone to work for personal or other people's gain. Corruption is rotten, evil, and destructive. If you talk about corruption, you will indeed find such a reality because corruption involves moral aspects, bad nature, and conditions, positions in government agencies or apparatus, abuse of power in office due to gifts, economic and political factors, as well as placing families or groups into groups. service under his jurisdiction. Corruption is an act to enrich oneself or a group is an act that is very detrimental to other people, the nation, and the state.

Corruption is a disease that has plagued Indonesia. Like a disease, this corruption must be cured so that it does not spread to other parts of the body. For body parts that have rotted and cannot be saved anymore, then that body part must be amputated so that the virus does not spread to other parts that can endanger the life of the sufferer. Likewise with corruption. Corruption is behavior that deviates from the official duties of a state position because of personal gains in status or money (individuals, close family, own groups), or violates the rules for implementing some personal behavior [12].

The elements of a criminal act of corruption are listed in Article 2 paragraph (1) of Law Number 31 of 1999 Jo. Law Number 20 of 2001 concerning Corruption Crimes reads "Every person who unlawfully commits an act of enriching himself or another person or a corporation that can harm state finances or the country's economy. Corruption is a criminal act that enriches oneself by directly or indirectly harming the country's finances and economy.

The crime of corruption (Tipikor) is a violation of the rights of the community, both economic and social. Corruption is no longer classified as an ordinary crime but has become an extraordinary crime (extra-ordinary crime). As a result of corruption, suffering is always experienced by the community, especially those who are below the poverty line.

\section{Return of State Financial Losses}

State finances are the lifeblood in the development of a country and will determine the continuity of the economy, both now and in the future. According to Law Number 17 of 2003 concerning State Finances, formulating the definition of state finances is all rights and obligations of the state that can be valued in money, as well as everything in the form of money or in the form of goods that can be used as state property related to the implementation of these rights and obligations. State financial losses are reduced state assets caused by abuse of authority or opportunities or 
facilities available to a person because of his position and position.

State financial losses can occur in two stages, namely at the stage where the funds will go to the state treasury and at the stage where the funds will go out of the state treasury [13]. At the stage where the funds will go into the state treasury, losses can occur through tax conspiracies, fines, refunds of state losses, and smuggling, while at the stage where the funds will come out of the state treasury, losses are incurred due to markups, corruption, implementation of activities that are not following the program and others. Acts that can harm the country's economy are criminal violations of the regulations issued by the government in the field of its authority.

The theory of recovering state financial losses is a legal theory that explains the legal system of returning state financial losses based on the principles of social justice that provides the capabilities, duties, and responsibilities to state institutions and legal institutions to provide protection and opportunities to individuals in society in achieving prosperity. This theory is based on the basic principle of "Give to the state what is the right of the state [14]." The state's rights contain state obligations which are individual rights of the community so that the principle is equivalent and congruent with the principle of "give the people what the people's rights are".

Return of State Financial Losses has been regulated in 4 (four) ways commonly used, including:

- Confiscation of movable property: confiscation of movable property is regulated in Article 18 paragraph (1) letter an of Law Number 31 of 1999 jo. Law Number 20 of 2001 concerning the Eradication of Corruption Crimes. This confiscation of movable property is carried out if the convict does not carry out the judge's decision to pay replacement money.

- Payment of Compensation Money: In the corruption law that has ever been in effect in Indonesia, the application of substitute money was first contained in Law Number 3 of 1971. According to this law, the payment of compensation must be the same as the amount of money that was corrupted.

There is a weakness in Law Number 3 of 1971 regarding replacement money, the article in the law does not specify when the deadline for payment of the replacement money is so that Law Number 31 of 1999 contains the maximum limit for the payment of the replacement money. Payment of replacement money is regulated in Article 18 paragraph (1) letter b of Law Number 31 of 1999 jo. Law Number 20 of 2001 concerning the Eradication of Corruption Crimes.

Payment of compensation is an additional crime in Indonesia's corruption laws. Additional penalties cannot be imposed separately but are imposed together with the main punishment. Payment of replacement money is an effort to restore the state's financial condition to its original state for losses to the state or the state economy created by criminal acts of corruption. The payment of replacement money is the imposition of additional penalties against the corruption defendants as mentioned in Article 18 of the Law paragraph (1) letter $b$ along with the imposition of the main criminal offenses in Article 2 and Article 3 of the Anti-Corruption Law. Law violations in Article 2 and Article 3 of the Corruption Law are dominated by cases of procurement of goods and services aimed at directly or indirectly building the economy.

The strategy of criminal law enforcement to overcome the dynamics of the replacement money crime is to apply the concept of progressive law that is faithful to the great principle of "law for humans". Progressive legal concretization in the strategy to overcome the problem of replacement money is carried out by making legal breakthroughs (rulebreaking) in the form of confiscation of collateral for property assets. Perpetrators regardless of asset statusrelated or not to corruption. Efforts to confiscate collateral are carried out solely to anticipate that the assets that will be the object of replacement money do not transfer to other parties and make it easier for prosecutors to carry out executions when the judge imposes a substitute money sentence on the defendant. In the corruption perception index data every year, Indonesia is still ranked 90 out of 176 countries with a score of 37.

Apart from the large costs resulting from criminal acts and the threat of crime occurring in society, the basic thing from the rationality of criminal acts is not minimizing the social costs arising from criminal acts. The schedule for payment of replacement money as stated in the Anti-Corruption Law within a month, which then in the next stage is the confiscation of the convict's assets, does not clearly state the time required to complete the search/tracking of the convict's assets and the time required to conduct the auction process for the assets after the convict can be obtained by the state. Determination of the time limit for the process of finding the convict's assets for state refunds, the period for the completion of the state refund process should be determined

In carrying out a court decision, in particular the decision on the Payment of Compensation Money as a form of additional punishment contained in the law on eradicating criminal acts of corruption against financial or economic losses that have been suffered by the State/Region, in its implementation it does not always run smoothly, sometimes there are obstacles or obstacles experienced by the prosecutor as the executor of court decisions and of course complicates the execution. 


\section{RESEARCH METHODS}

Research has another term or known as research. The research comes from English, namely research which comes from the word re (re) search (search) this research which has the term research can be interpreted as searching again. This research activity is based on the curiosity of someone who is then referred to as a researcher in carrying out research activities. Research is a form of expression of curiosity carried out in the form of scientific research activities. This research is carried out with a sense of trust in the object being researched by finding out the causes and effects that arise or occur in the object of research.

This study uses a normative research method. Normative legal research is a process to find a rule of law, legal principles, and legal doctrines to answer the legal issues faced. In this type of legal research, the law is often conceptualized as what is written in legislation or the law is conceptualized as a rule or norm which is a benchmark for human behavior that is considered appropriate.

Based on the problem approach and the required data sources, the data collection in this study was carried out through a literature study by reading, quoting, taking notes, and identifying data that was following the problem, and collaborating with the data of applicable laws and regulations. After collecting data, then processing the data obtained is used to analyze the problems studied. Data processing in this study was carried out by Data examination, classification, and data compilation.

\section{RESULTS}

\section{A. The Urgency of Revitalizing Pancasila Values Against the Imposition of Substitution Money in Corruption Crimes.}

All nations in the world have historical, cultural, and civilizational backgrounds that are imbued with a value system and philosophy, both religious moral values (theism-religious) and non-religious values (secular, atheism). Strictly speaking, every nation always upholds the values of its civilization by being inspired, based on, and guided by religious or nonreligious values. Likewise, with the pluralistic and multicultural Indonesian nation, life in society, nation, and state is colored by strong religious beliefs and beliefs. On the other hand, social, cultural, political, and economic aspects also characterize the constitutional life of a nation.

Pancasila is often seen as an ideology that deals with global ideologies, such as capitalism and liberalism [15]. The Pancasila that was built was for the common welfare and social justice for all Indonesian people. On the other hand, we live in globalization that is full of the laws and rules of capitalism, free and open markets. We must remain firm in our stance, that we will continue to dedicate all of these things to the common good, to social justice. An intelligent nation in the era of globalization is not a nation that continues to complain, give up, and get angry, but a nation that can drain the sources of prosperity available in the global arena. We all use technology, capital, or information properly to improve our welfare and interests. Don't want to be the loser.

Since the Reformation era, Pancasila is rarely expressed and conveyed by officials and is no longer a public discourse that is discussed and discussed by various groups of people. This phenomenon is most likely because in the past before the Reformation there was excessive use of Pancasila, even it became a legitimacy tool and was interpreted by the authorities themselves for the benefit of power. The current condition in which Pancasila plays less of a role in national and state life is certainly very detrimental to the interests of the nation and state which requires the main guidance in state administration and development. In addition, it also requires a major filter from the invasion of foreign understandings, systems, ideologies, and cultures through globalization, all of which are obtained from Pancasila [16].

Juridically Pancasila was ratified and stipulated as the basis and philosophy of the state through the PPKI session on August 18, 1945. The state philosophy (philosophy sche grondslag) in Soekarno's term, has existed sociologically since Indonesia was not yet independent, which has its roots in cultural values. Indonesian society and nation which is extracted from the view of the life of the Indonesian nation.

The state recognizes two types of ideology, namely; a) Closed type, namely ideology is not born from the will of a particular community, but from a certain group that aims to renew and change the community so that the truth of values is certain and must be accepted by all levels of society in the country because it is dogmatic and a priori. b) Open type, namely ideology born and extracted from values born from the community itself which is not forced from outside and also not from the will of certain groups.

From the criteria for the two types above, Pancasila is an open ideology. This is because Pancasila as an ideology is explored and found from the values that live in Indonesian society itself which is responsive to the dynamics of the life of the nation and state. This is in stark contrast to the ideology of socialism-communism and the ideology of capitalismliberalism. The ideology of Pancasila recognizes and 
protects the rights of individuals and the rights of the community both in the economic and political fields.

The open ideology of Pancasila requires every person or legal entity to be fair to others, starting from enforcement to imposing sanctions on the application of applicable laws. The imposition of sanctions against criminals must also pay attention to the existing Pancasila values, by being relevant to these values. The revitalization of Pancasila will make efforts to re-excavate the philosophical norms of Pancasila to become the spirit and foundation for the formation of moral guidance and become the basis for legal norms in Indonesia. Thus there is a close relationship between the process of fostering the nation's morals and the support of the resulting legal products so that Pancasila morality will be meaningful if it is supported by legal provisions based on the philosophical values of Pancasila.

The crime of corruption is an act against the law which is very contrary to the original character (basic character) of the Indonesian nation which has been rooted for a long time in the heart. The nobility of character, the height of aesthetic value, living together (communal) upholding human rights, belief in divinity, and social justice are the personality traits of the Indonesian nation. While a culture of corruption that tends to promise glamour, hedonism and will have an impact on the formation of a capitalist individualist moral personality, this is not the character of the original Indonesian nation.

Pancasila as a legal ideal is an idea from the culture of the community itself, or in other words, the legal ideal of Pancasila as a building of thought that directs the law to the ideals aspired by the Indonesian people. As stated by Arif Sidharta that the legal ideals of Pancasila are a reflection of the life of the nation and state in Indonesia which have the core:

- Belief in the one and only God;

- Respect or human dignity;

- Insight of nationality and insight of the archipelago;

- Equality and culture;

- Social justice;

- High morals and character;

- Community participation and transparency in public decision-making processes.

In this case, the normative crime of corruption is not only detrimental to the state but also gives a negative stigma to the thoughts of corrupt actors. This is because the imposition of criminal sanctions given can choose when the verdict is handed down by the judge. The criminal sanctions imposed by the judge's decision on recent corruption crimes are limited to imprisonment and confiscation of assets owned by the perpetrators of criminal acts of corruption.

The proliferation of criminal acts of corruption has certainly made the entire Indonesian nation worse off. It turns out that corruption occurs in various sectors as well as executive, legislative, and judicial powers as well as the private sector. Therefore, eradicating corruption is one of the main focuses of the Government and the Indonesian Nation. Efforts have been taken, both to prevent and eradicate corruption simultaneously, considering that corruption is a white-collar crime as well as an extraordinary crime. These efforts have been carried out and strived to produce results in the form of growing intention to eradicate corruption in remote parts of Indonesia [17].

Based on ICW's records throughout the first semester of 2020 , the total state financial losses amounted to $\mathrm{Rp} 39.2$ trillion. Meanwhile, the additional penalty for replacement money is only $\mathrm{Rp}$. 2.3 trillion. These data show that as a result of corruption in Indonesia, state losses are very large, even replacement money that returns to the State treasury is inversely proportional, therefore changes are needed in the field of existing criminal sanctions, replacement money must be used as a principal crime not an additional crime in criminal acts corruption crime. Thus, the perpetrators of criminal acts should return the losses due to their actions, so that the State can optimize the development of both infrastructure and others.

Accountability for state finances with the dimensions of harming and or not harming state finances in the perspective of criminal law must be based on the principles of legality, legal certainty, benefit, justice, proof theory and aims to save state finances from the perpetrators so that state losses can be returned with an effective law, namely through fines and compensation without imprisonment. The corruption that has been happening systemically and widely has not only harmed the state, disrupted the stability and security of society, and weakened democratic values, ethics of justice, and legal certainty, thus endangering the continuity of development, but also violated social rights and the general economy, which is bad behavior that tends to be difficult to tackle and corruption is classified as a crime that must also be eradicated extraordinarily. The crime of corruption harms the economy of a country, becoming a high-cost economy.

The implementation of the payment of compensation money is dynamic because the additional criminal rules in Law Number 31 of 1999 
concerning the Eradication of Criminal Acts of Corruption provide space for judges to subordinate the substitute money sentence to a relatively short prison sentence. Empirical reality shows that there is a tendency for convicts of corruption to choose to undergo subsidiary punishments rather than paying replacement money because the weight of subsidiary crimes is much lighter and quite economical than having to compensate the state so that the state is still economically losing and the corruption perception index continues to increase.

The strategy of criminal law enforcement to overcome the dynamics of the replacement money crime is to apply the concept of progressive law that is faithful to the great principle of "law for humans". Progressive legal concretization in the strategy to overcome the problem of replacement money is carried out by making legal breakthroughs (rulebreaking) in the form of confiscation of collateral for property assets. Perpetrators regardless of asset statusrelated or not to corruption. Efforts to confiscate collateral are carried out solely to anticipate that the assets that will be the object of replacement money do not transfer to other parties and make it easier for prosecutors to carry out executions when the judge imposes a substitute money sentence on the defendant. In the 2016 corruption perception index data, Indonesia is still ranked 90 out of 176 countries with a score of 37 .

Pancasila is a reflection of the personality of the Indonesian people, which is an ideal value that was well outlined by the nation's founders. When formulating Pancasila, there was a debate that led to how the best model of Indonesian people would be in the future. Through intensive discussions and intellectual debates, a grand conception of Pancasila was born and has lofty ideals. For this reason, all forms of deviation in Indonesian society should be returned to the weak understanding and experience of the Indonesian people on Pancasila.

Social justice for all the people of Indonesia. There is no more justice when social inequality is widening because the state budget is no longer propeople. On the other hand, if the fifth precept is used as the basis for enforcing criminal sanctions in exchange for criminal acts of corruption. So that in the imposition of criminal sanctions, substitute money is used as a principal crime, it is something that should be done, so that the Pancasila value of social justice becomes the basis that must be prioritized. Therefore, the applicable law and the sanctions applied to use the principle of justice and the principle of public peace [18]

After all, corruption is like the proverbial drop of indigo, a pot of milk is damaged. One Indonesian man commits corruption, the impact is felt by all Indonesian people. Corruption will damage national unity because it causes national development to stop. After all, development funds are corrupted by certain individuals. A corruptor is also a bad example for the next generation because it creates a negative value that if you want to be rich, then corruption. This is the thought of the corrupt who want to enrich themselves. The emphasis that needs to be done is on the perpetrators of corruption, the punishments, and sanctions given are not only imprisonments but the amount of corruption that exists must be replaced with replacement money.

Obstacles in the execution process for the payment of replacement money as mentioned above are not impossible to often encounter, because the perpetrators of criminal acts of corruption currently have certain qualities, both in terms of ability, position, and social status. Perpetrators of criminal acts of corruption are generally educated people, in addition to having a position of authority or opportunity. The process of globalization in the life of modern society, accompanied by the rapid development of science and technology, has had a broad impact with the increasing variety of modus operandi of corruption. Someone who has a fairly high intellectual level in committing corruption can cover up his actions so that it runs neatly, smoothly, and for a fairly long period.

The substitute money punishment does not have an alternative punishment (subsidiary) such as a fine that can be subsidized with imprisonment, and therefore is not an opportunity for the convict to choose which punishment he will carry out. This choice has deviated from the true meaning of subsidiary, namely from a substitute if the main thing does not happen, to a choice. This condition was ultimately used by the convicts - who were supported by the conditions and limitations of handling corruption cases - to be able to easily admit that they no longer had the assets to pay the replacement money, and "choose" a substitute prison sentence that was more profitable for them, especially supported by the possibility of the convict being released more quickly because of the granting of remissions at certain times.

Thus the urgency in the relevance of the value of Pancasila as substitute money for corruption in Indonesia. the payment of replacement money in practice does not protect the economic rights of the community that has been lost over time until the decision has permanent legal force, the payment of replacement money is only based on the amount obtained by the defendant as a result of a criminal act of corruption. This is an additional form of punishment that can be imposed on corrupt 
defendants. The imposition of this additional crime is one way to restore the state's financial condition to its original state and provide a direct deterrent to the consequences of corruption crimes.

\section{B. The Problem of Dropping Replacement Money in the Crime of Corruption}

In general, the Prosecutor's Office of the Republic of Indonesia as a government institution has functions and authorities in the field of law enforcement and authorities related to maintaining order and peace. The law enforcement function of the prosecutor's office in the field of criminal law has been described in the prosecutor's statutory rules in Article 30 paragraph 1 of the prosecutor's law which explains that the duties and authorities include prosecutions that already have a permanent law, supervision on the implementation of conditional criminal decisions, and release decisions. Conditional, the existence of investigative treatment in certain criminal acts based on legislation, completion of case files, and being able to carry out additional examinations on a file before it is delegated to a court whose execution is coordinated with investigators.

The prosecution is a series of actions taken to transfer the files of a case to an authorized court which is carried out by the public prosecutor so that the files that are continued for examination in court are examined and decided by the judge. Indonesia's positive law stipulates that prosecutions are only carried out to the prosecution agency in this case the public prosecutor following the dominus litis principle which has a strategic role in determining whether or not a case can be forwarded to court. The public prosecutor's agency itself can come from the prosecutor's office and the KPK. The public prosecutor from the KPK is in charge of prosecuting specifically in corruption cases, while the public prosecutor from the prosecutor's office is in charge of prosecuting all types of criminal acts except for military crimes by military prosecutors.

The Prosecutor's Office which is based in the same organization as the Prosecutor's Office, in its understanding of its duties and authorities in Article 2 paragraphs 1 to 3 of Law Number 16 of 2004 concerning the Prosecutor's Office shows that the position of the Prosecutor's Office is classified as a dilemma because it is facing a dual obligation situation, namely one the side as law enforcers who carry out duties regarding the prosecution power who must act independently free from any intervention from any party including the executive (President) on the other hand as state officials (the President's subordinates) in the context of government management with the attorney general who must have high loyalty to the government. This dilemmatic position can also be affected by the independence of the prosecutor's office in prosecution as an effort to enforce the law in the criminal justice system.

Independence by the attorney general's office is very much needed in efforts to enforce the law with integrity and restore public confidence in the current poor law enforcement system in Indonesia. Independence itself means freedom, independence, independence or not being under the control/supervision of other institutions. The Prosecutor's Office as a law enforcement officer who enters the judicial power must be independent and independent in carrying out every law enforcement process in the judicial power. The power of the judiciary itself must be expanded not only in terms of the judiciary but also in every element of the law enforcement process, starting from the investigation, prosecution, court, criminal execution. Therefore, in carrying out the judicial power, it should be integrated independence.

Article 2 Jo. Article 18 and Article 19 of Law Number 16 of 2004 place the prosecutor's office in a position that is not independent and ambiguous both in terms of accountability to superiors and in judicial power so that it has an impact on law enforcement actions which are often hesitant, not firm and even abuse of power by accepting bribes. The actions of prosecutors who have deviated show that there is a legal culture of prosecutors that has been eroded by the beauty of money that can solve all cases by him. Legal culture is a crucial element in understanding the differences that lie in one legal system with another. Legal culture is closely related to issues of values, legal awareness, and public behavior which have implications for the operation of the law.

Lawrence M. Friedman divides the various components in shaping legal culture into 3 (three) parts, namely: structure, substance, and culture. If it is related to the legal system at the prosecutor's office, the structural component concerning the prosecutor's institution that wants to be created is like a prosecutor who is free of corruption, independent, and independent so that with the benchmark/objective to be achieved, the prosecutor's agency can apply and be used as a benchmark so that in carrying out its duties it must integrity, honesty, and obedience. The substance component is the content aspect of the legal system itself, which includes norms in the embodiment of statutory regulations.

In the prosecutor's office, with the dual obligations that occur, reconstruction is needed in terms of substance to make the prosecutor's agency independent and free in law enforcement. Meanwhile, the cultural component is the values and attitudes that bind the system and determine the place of the system 
amid the nation's culture, such as community legal awareness in law enforcement. In the culture of the prosecutor's office, legal awareness is needed from the prosecutor, starting from binding legal regulations, the law-making body, the law/sanctions implementing body, the community, in this case, the awareness of the prosecutor and others.

Various eradication efforts have not been able to completely eradicate corruption. Eradication of corruption legally is by relying on the consistent implementation of the Law on the Eradication of Criminal Acts of Corruption and various related repressive provisions. The law in question is Law Number 31 of 1999 concerning Eradication of Criminal Acts of Corruption, as amended by Law Number 20 of 2001 concerning Amendments to Law Number 31 of 1999 concerning Eradication of Criminal Acts of Corruption. Then in carrying out efficient and effective eradication of corruption, it is necessary to support good governance management and international cooperation, including the return of assets originating from criminal acts of corruption,

The return of financial losses/state assets is a consequence of the consequences of criminal acts of corruption that can harm the state's finances or the state's economy so that to restore these losses, juridical means are needed, namely additional penalties in the form of payment of replacement money. The purpose of the crime of replacement money is to punish the corruptors as severely as possible so that they are deterred, as well as to restore state finances lost due to an act of corruption, where this effort produces results in the form of income to the state treasury from the proceeds of paying the replacement money.

Based on the Letter of the Attorney General of the Republic of Indonesia Number: B012/A/Cu.2/01/2013 dated January 18, 2013, concerning Accounting Policies and Guidelines for Settlement of Receivables Receivable in Compensation for the Indonesian Attorney's Office defines that, replacement money is one of the additional criminal penalties in cases of Corruption crime that must be paid by the convict to the state in the maximum amount equal to the assets obtained from the criminal act of corruption. Replacement money occurs as a result of a court decision that has permanent legal force (inkracht) imposed on the convict to be paid/returned to the state, through the state treasury/regional treasury/BUMN/BUMD or replaced with a criminal entity (subsidiary) if you do not pay the replacement money.

In the process of returning state financial losses through the imposition of sanctions for payment of compensation for the corruption crime, the convict is required to be punished with additional compensation money in the maximum amount equal to the property obtained from the proceeds of the criminal act of corruption and not merely several state financial losses caused. If the judge imposes an additional penalty in the form of payment of replacement money, the convict is given a grace period of 1 (one) month to pay it off after the court's decision has permanent legal force (inkracht), where after the payment is made by the convict, the Prosecutor will deposit the proceeds of the payment to the State Treasury to pay the replacement money for the convict,

Recovering state losses is not easy because corruption is an extraordinary crime whose perpetrators come from intellectual circles and have important positions, and also because the judicial process for corruption, in general, takes a long time. Problems encountered in recovering state financial losses through the imposition of sanctions for payment of compensation for corruption include; the convict does not pay the replacement money charged to him, and the convict does not have sufficient property to pay the replacement money charged to him [19].

If after the confiscation the convict still does not pay the replacement money charged to him, then the Prosecutor is obliged to auction off the convict's property no later than 3 (three) months after the confiscation, in which the essence is to restore state financial losses. After the auction of the convict's property, the Prosecutor will deposit the proceeds of payment to the State Treasury to pay the convict's replacement money, then send a copy of the minutes of the auction to the District Court adjudicating the case.

To pay off the replacement money charged, the Prosecutor may confiscate and auction the property of the convict after the court's decision has permanent legal force. However, if this provision is implemented, the Prosecutor will encounter obstacles in finding the property of the convict or his heirs, and the potential for arrears or non-payment of replacement money charged to the convict is very large. Then regarding how to overcome the obstacles encountered in the payment of replacement money in the criminal act of corruption as referred to above, among others, the convict who does not pay the replacement money, the Prosecutor is obliged to confiscate the property owned by the convict. If within 3 (three) months after the confiscation the convict still does not pay the replacement money, then the Prosecutor auctions the property belonging to the convict, where the results of the auction are deposited with the State Treasury. Upon the payment of part of the replacement money charged, the 
Prosecutor will determine a reduction in the length of substitute imprisonment (subsidiary compensation) that the convict must serve proportionally before the main prison sentence is completed.

\section{CONCLUSION}

The open ideology of Pancasila requires every person or legal entity to be fair to others, starting from enforcement to imposing sanctions on the application of applicable laws. The imposition of sanctions on criminals must also pay attention to the existing Pancasila values, by being relevant to exist values. The revitalization of Pancasila will make efforts to reexcavate the philosophical norms of Pancasila to become the spirit and foundation for the formation of moral guidance and become the basis for legal norms in Indonesia. The urgency in the relevance of the value of Pancasila as substitute money for corruption in Indonesia. The payment of replacement money in practice does not protect the economic rights of the community that has been lost over time until the decision has permanent legal force, the payment of compensation is only based on the amount obtained by the defendant as a result of a criminal act of corruption. The problems encountered in recovering state financial losses through the imposition of sanctions for payment of compensation for corruption include; the convict does not pay the replacement money charged to him, and the convict does not have sufficient property to pay the replacement money charged to him. Then the way to overcome this is, for the convict who does not pay the replacement money, the Prosecutor is obliged to confiscate and auction the property owned by the convict, and deposit the results of the auction to the State Treasury; then for the convict who does not have sufficient property to pay the replacement money, the repayment of the arrears of the replacement money is carried out through a subsidiary claim to imprisonment, or a corporal punishment whose duration does not exceed the maximum threat of the principal sentence and has been determined in a court decision (subsidiary compensation). If there is still property belonging to the convict which is suspected or reasonably suspected to have originated from a criminal act of corruption that has not been confiscated for the state, then the state through the State Attorney or the agency that has been harmed may file a civil lawsuit against the convict and/or his heirs to pay compensation. as determined by the judge who decides the corruption case in question.

\section{REFERENCES}

[1] Arif Siddhartha, Bernard, 'Reflection on Structure...,'Bandung: Mandar Maju, 2000.

[2] Dipoyudo, Kirdi, Social Justice, 'Series on the appreciation and practice of Pancasila,' Jakarta, Rajawali, 1995.

[3] Ekaputra, Mohammad and Abul Khair, The Criminal System in the Criminal Code and Its Arrangements According to the Concept of the New Criminal Code, USU Press, Medan, 2010.

[4] Prasetyo, Teguh. 2013. Law and Legal System based on Pancasila (Yogyakarta: Media Perkasa).

[5] Sukarno's daughter, Megawati. 2012. National speech commemorating the birthday of Pancasila June 1, 2012 in the book History and Spirituality of Pancasila, Pen.PDIP-MPRRI, Garmedia.

[6] Rahardjo, Satjipto. 2008. Dissecting Progressive Law, Jakarta, Kompas Book Publisher.

[7] Ade Mahmud. "The Dynamics of Payment of Compensation in Corruption Crimes." Journal of Law pulpit Justitia 3, no. 2 (2017): 137-56

[8] Agus Riwanto. "Realizing Just Law Progressively from the Perspective of Pancasila." Al-Ahkam 2, no. 2 (2017): 138-51.

[9] Budiman, Mama. "Corporate Crime in Indonesia." Equivalent to Press 29, no. 2 (2020): 12.

[10] Goddess, Princess Maha. "A Study on Globalization Development in Indonesia's National Law Development Policy Formulation." July 2, no. 1 (2019): 42.

[11] Dinah, Angelina. "Pancasila Values in Dealing with Corruption in Indonesia,” 2019. https://doi.org/10.31219/osf.io/zaxvt.

[12] Wisdom, Princess. "Returning State Financial Losses From Payment of Money to Replace Corruption Crimes, Can It Be Optimal? (Return of State Financial Losses from The Payment of Substitute Money Corruption Criminal Act, Can It Be Optimal?).” The Rule of Law: Building Laws for Justice and Prosperity 10, no. 1 (2019): 89-107. https://doi.org/10.22212/jnh.v10i1.1217.

[13] Indra Ariska, Dudung. "Payment of Substitution and Its Application in Corruption Crimes." Yustitia 4, no. 2 (2018): 142-61. https://doi.org/10.31943/yustitia.v4i2.43.

[14] Christiano, Christmas. "Strengthening Pancasila Ideology Among Semarang State University Students." Harmony 2, no. 2 (2017): 193-204. https://journal.unnes.ac.id/sju/index.php/harmony/article/view /20171/9563.

[15] Mahmud, Ade. "Transformation of Pancasila Values in Renewing the National Criminal Law." Journal of Law pulpit $\begin{array}{llllll}\text { Justitia } & 4, & \text { no. } & 1 & \text { (2018): } & 1 .\end{array}$ https://doi.org/10.35194/jhmj.v4i1.352.

[16] Muhlizi, Arfan Faiz. "Mental revolution to shape an anticorruption legal culture." Rechts Vinding Journal: National Law Development Media 3, no. 3 (2014): 453. https://doi.org/10.33331/rechtsvinding.v3i3.36.

[17] Nur, Syurya Muhammad, and Rahmah Ningsih. "Corruption Degrades the Ethical Values of Pancasila." Corruption Degrades the Ethical Values of Pancasila Scientific Forum 16, no. 3 (2019).

[18] Sinaga, Christine Juliana. "A Study on Prisons as a Subsidiary of Additional Criminal Payments for Substitution in Corruption Crimes." Juridika Insight Journal 1, no. 2 (2017): 191. https://doi.org/10.25072/jwy.v1i2.134. 